\title{
Fasciitis on Abdominal Craniectomy Implantation
}

\author{
Pierlesky Elion Ossibi1 ${ }^{*}$, Salima Rezzouk¹, Ibrahima Berete², KarimIbn Majdoub1, \\ Imane Toughrai', Said Ait Laalim¹, Abdelmalek Ousadden', Mohammed Chaoui El Faiz², \\ Khalid Mazaz' ${ }^{1}$ Khalid Ait Taleb ${ }^{1}$ \\ ${ }^{1}$ Visceral Surgery Department, Hassan II University Hospital, Fez, Morocco \\ ${ }^{2}$ Neurosurgery Department, Hassan II University Hospital, Fez, Morocco \\ Email: ${ }^{*}$ oselion@yahoo.fr
}

Received 21 August 2014; revised 18 September 2014; accepted 13 October 2014

Copyright (C) 2014 by authors and Scientific Research Publishing Inc.

This work is licensed under the Creative Commons Attribution International License (CC BY). http://creativecommons.org/licenses/by/4.0/

(c) (i) Open Access

\begin{abstract}
Necrotizing fasciitis is an infection of the skin and deep subcutaneous tissue. It is caused by bacteria (group A streptococcus), but may also be idiopathic ora secondary complication of surgery. We report a case of necrotizing fasciitis of the abdominal wall fostering a decompressive cranial flap in a 39-year-old patient.
\end{abstract}

\section{Keywords}

Fasciitis, Craniectomy, Abdominal, Implantation

\section{Introduction}

Necrotizing fasciitis is a rare infection of the skin and deep lying subcutaneous tissue spreading along the fascia and adipose tissue [1]. This is a condition that is usually caused by group A streptococcus (Streptococcus pyogenes) [1] but also by other bacteria. This infection may be idiopathic or more often secondary to a local trauma or surgery. It mainly affects patients: over 50 years old, diabetic, having peripheral vascular disorder, alcoholics, obese and immunocompromized [2]. Its mortality rate is estimated at 30\% [1]. We report a case of necrotizing fasciitis of the abdominal wall fostering a decompressive cranial flap in a 39-year-old patient.

\section{Case Presentation}

39-year-old female, of Moroccan descent, with a history of epilepsy admitted in Neurosurgery with frontal lobe

${ }^{*}$ Corresponding author.

How to cite this paper: Ossibi, P.E., Rezzouk, S., Berete, I., Majdoub, K., Toughrai, I., Laalim, S.A., Ousadden, A., El Faiz, M.C., Mazaz, K. and Taleb, K.A. (2014) Fasciitis on Abdominal Craniectomy Implantation. Surgical Science, 5, 479-482.

http://dx.doi.org/10.4236/ss.2014.510073 
tumor for which biopsy and partial resection was performed. The clinical course was marked by the occurrence of intracranial hypertension which was the subject of revision surgery: decompressive cranial flap fostered in the abdominal cavity.

Postoperative Recovery was marked, on the second day, by the occurrence of abdominal and pelvic infiltration with fever.

On physical examination, patient was under non-invasive monitoring, urine and nasogastric tubes inserted as well as intravenous access secured and consciousness level at 11 on the Glasgow Coma scale. Patient was hemodynamically stable, with blood pressure $110 / 70$, a heart rate 92 beats/minute, febrile $38.8^{\circ} \mathrm{C}$ and aright lower para rectal incision with large warm skin rash extending from the right flank to the root of the thigh (Figure 1).

Laboratory tests showed biological inflammatory syndrome with neutrophilic leukocytosis and elevated CRP.

Abdominal ultrasonography showed an abundant intraperitoneal effusion notably with bilateral perivesical effusion and infiltration of the psoas.

An abdominal CT scan revealed hematoma around the flap with the presence of air bubbles (Figure 2) and abundant ascites.

The patient was re-admitted to the operating room where she underwent flap removal (Figure 3), incision and drainage coupled with empirical antibiotherapy.

Postoperative recovery was uneventful as far as the abdominal wall was concerned and patientcontinued subsequent neurosurgical management.

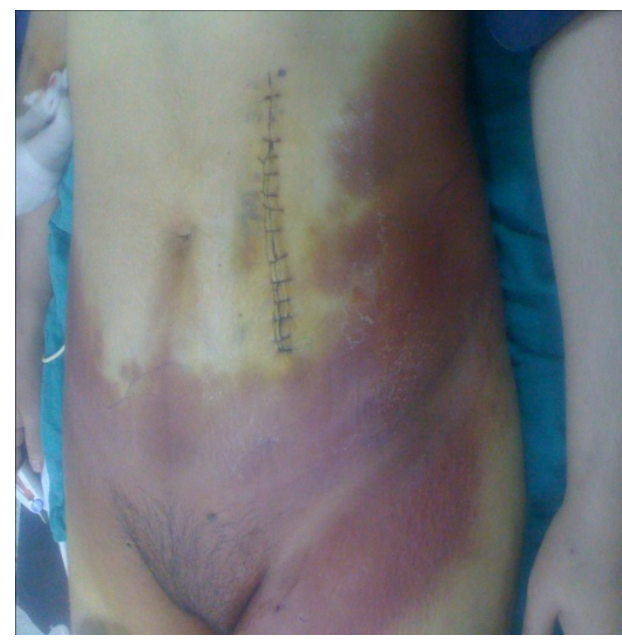

Figure 1. Large erythematous skin rash.

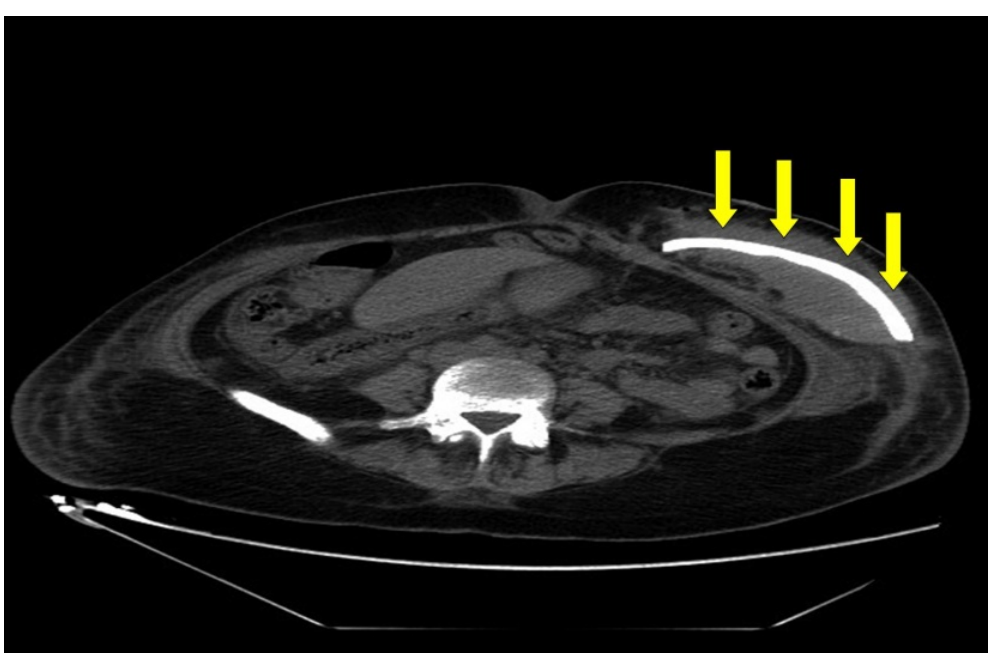

Figure 2. Abdominal CT scan showing decompressive craniectomiy. 


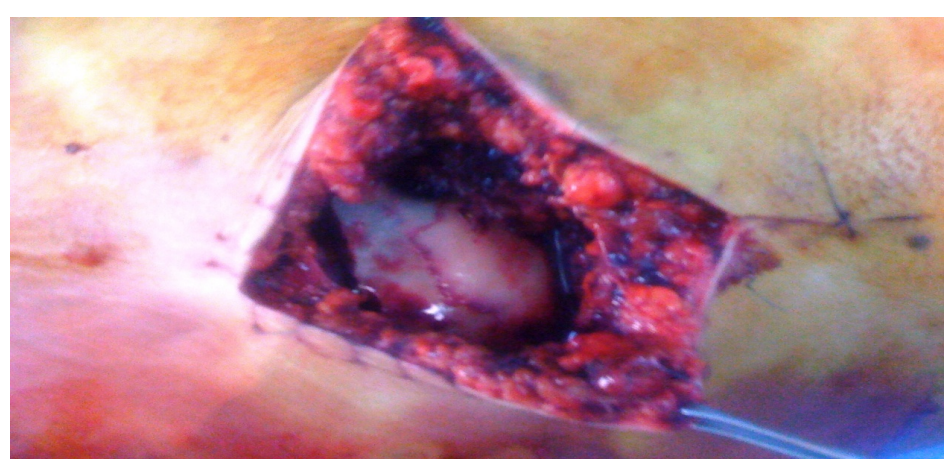

Figure 3. Per operative image showing decompressive craniectomy.

\section{Discussion}

Necrotizing fasciitis is an outstanding infectious disease with grim local and general prognosis. The infection primarily affects the extremities, abdomen, back, genitals and peri anal region.

There is very few data regarding the epidemiology of necrotizing fasciitis. For invasive group A streptococcal infections, 5\% - 10\% necrotizing fasciitis have been reported in the USA and Canada [3] [4]. Fournier gangrene is still rare considering only 1726 cases have been reported in the literature [5].

Generally, it is a condition that is caused mainly by group A streptococcus (Streptococcus pyogenes) [1] as well as other bacteria. It may be idiopathic or more often due to local traumatism or surgery (abdominal surgery, hemorroidectomy, vasectomy, episiotomy, liposuction) [6] as in our case. It mainly affects patients; over 50 years old, diabetic, having peripheral vascular disorder, obese and immunocompromised [2]. Our case involved a young patient immunocompromised by his tumor, who presented a rare cause of abdominal wall fasciitis: a decompressive flap being fostered in the abdomen.

It requires urgent treatment. It is medical as it involves fluid resuscitation and antibiotherapy but especially surgical by debridement of dead tissues.

Due to the potential severity of these infections and progression to septic shock, it is important to hospitalize such patients in intensive care unit and to immediately initiate an empiric antibiotherapy aimed at anaerobes and Gram negative bacilli.

Till date, Surgery remains the most effective tool, irreplaceable and adeterminant factor in the prognosis of this affection. This procedure has to be performed as soon as possible with hyperbaric oxygen therapy installed. This multidisciplinary management must be initiated without delay [7].

Its mortality rate is estimated at 30\% [1] due to the severity of the condition, a prognosis which can be improved with early and appropriate management.

\section{Conclusion}

Necrotizing fasciitis is a major medical and surgical emergency, due to the degree of skin necrosis and high mortality. This condition has many causes, mainly surgery exceptionally abdominal craniectomy implantation. All decompressive cranial flaps being fostered in the abdomen should impose regular monitoring of the abdominal wall.

\section{References}

[1] McHenry, C.R., Piotrowski, J.J., Petrinic, D. and Malangoni, M.A. (1995) Determinants of Mortality for Necrotizing Soft-Tissue Infections. Annals of Surgery, 221, 558-563. http://dx.doi.org/10.1097/00000658-199505000-00013

[2] Green, R.J., Dafoe, D.C. and Raffin, T.A. (1996) Necrotizing Fasciitis. Chest, 110, 219-229. http://dx.doi.org/10.1378/chest.110.1.219

[3] Davies, H.D., McGeer, A., Schwartz, B., Green, K., Cann, D., Simor, A.E. and Low, D.E., Ontario Group A Streptococcal Study Group (1996) Invasice Group A Streptococcal Infections in Ontario, Canada. The New England Journal of Medicine, 335, 547-554. http://dx.doi.org/10.1056/NEJM199608223350803

[4] Stevens, D.L., Tanner, M.H., Winship, J., Swarts, R., Ries, K.M., Schlievert, P.M. and Kaplan, E. (1989) Severe Group A Streptococcal Infections Associated with a Toxic Shock-Like Syndrome and Scarlet Fever Toxin A. The New Eng- 
land Journal of Medicine, 321, 1-7. http://dx.doi.org/10.1056/NEJM198907063210101

[5] Eke, N. (2000) Fournier’s Gangrene: A Review of 1726 Cases. British Journal of Surgery, 87, 718-728. http://dx.doi.org/10.1046/j.1365-2168.2000.01497.x

[6] Czymek, R., Frank, P., Limmer, S., Schmidt, A., Jungbluth, T., Roblick, U., Bürk, C., Bruch, H.P. and Kujath, P. (2010) Fournier's Gangrene: Is the Female Gender a Risk Factor? Langenbeck's Archives of Surgery, 395, 173-180. http://dx.doi.org/10.1007/s00423-008-0461-9

[7] Sorensen, M.D., Krieger, J.N., Rivara, F.P., Klein, M.B. and Wessells, H. (2009) Fournier’s Gangrene: Management and Mortality Predictors in a Population Based Study. The Journal of Urology, 182, 2742-2747. http://dx.doi.org/10.1016/j.juro.2009.08.050 
Scientific Research Publishing (SCIRP) is one of the largest Open Access journal publishers. It is currently publishing more than 200 open access, online, peer-reviewed journals covering a wide range of academic disciplines. SCIRP serves the worldwide academic communities and contributes to the progress and application of science with its publication.

Other selected journals from SCIRP are listed as below. Submit your manuscript to us via either submit@scirp.org or Online Submission Portal.
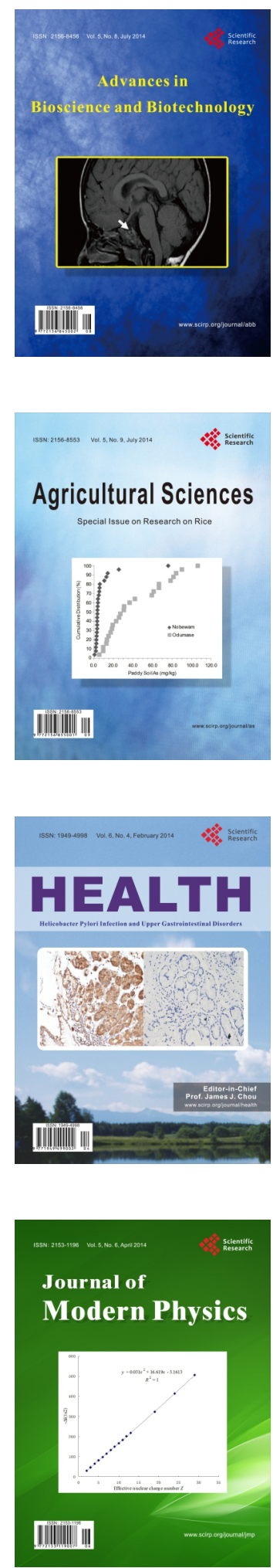
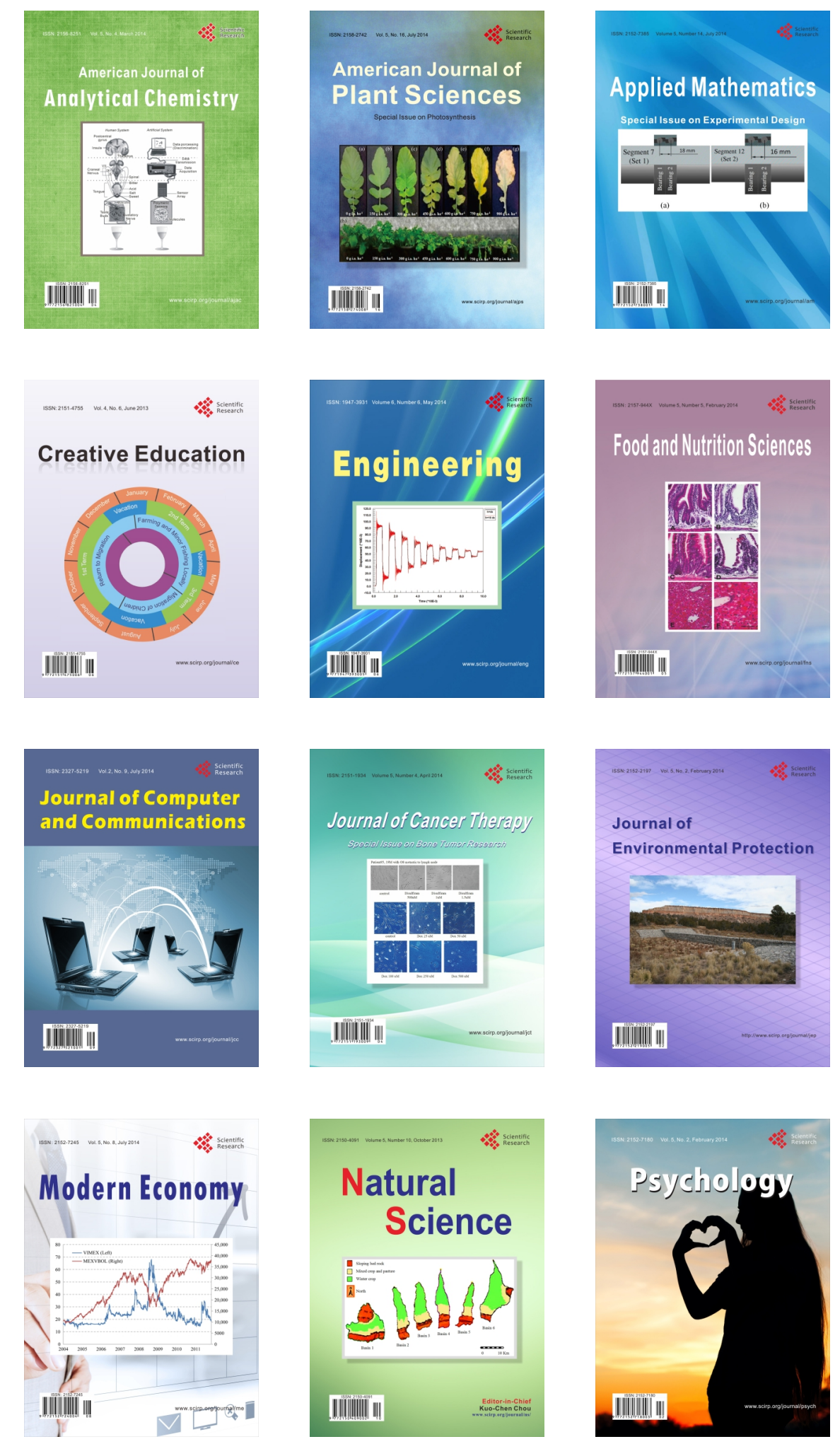